Jurnal Teknologi, 39(D) Dis. 2003: 75-86

(C) Universiti Teknologi Malaysia

\title{
DIAGNOSIS KEROSAKAN LITAR MENGGUNAKAN PSPICE DAN RANGKAIAN NEURAL TIRUAN
}

\author{
JASRONITA JASNI ${ }^{1}$, SAMSUL BAHARI MOHD NOOR ${ }^{2}$, \& RIBHAN ZAFIRA \\ ABD RAHMAN ${ }^{3}$
}

\begin{abstract}
Abstrak. Kerosakan komponen di dalam satu litar sangat sukar dikesan dan mengambil masa yang lama untuk dikenalpasti. Kertas ini membentangkan kaedah mendiagnosis kerosakan litar menggunakan Rangkaian Neural Tiruan (RNT). Litar Pengayun dan Pulse Width Modulator yang merupakan sebahagian dari Switch Mode Power Supply telah digunakan sebagai litar kajian. Litar ini disimulasi menggunakan Pspice dan data voltan pada nod direkodkan dan digunakan dalam sistem rangkaian neural tiruan. Setelah dilatih, sistem ini berupaya mengenalpasti komponen yang rosak dengan mudah.
\end{abstract}

Kata kunci: Diagnosis kerosakan, litar analog, rangkaian neural

Abstract. Faulty components in a circuit is difficult and time consuming to be identified. This paper presents a method of circiut fault diagnosis using artificial neural networks (ANN). Oscillator circuit with Pulse Width Modulator which is part of a Switch Mode Power Supply is used in this study. The system is trained and able to identify the individual faulty components with ease.

Keywords: Fault diagnosis, analog circuit, neural network

\subsection{PENGENALAN}

Apabila terdapat komponen di dalam litar elektrik mengalami kerosakan, ia akan menyebabkan perubahan aras arus dan voltan serta frekuensi pada mana-mana titik di dalam litar tersebut. Pengujian menggunakan kaedah biasa bagi komponen yang masih di dalam litar tidak boleh dipercayai sepenuhnya memandangkan komponen bersambungan antara satu sama lain.

Satu pendekatan telah dikemukakan seawal 1985 yang mangkategorikan diagnosis kerosakan litar kepada dua iaitu simulasi sebelum ujian dan simulasi selepas ujian [1]. Kamus kerosakan diperlukan bagi kategori pertama dan ia hanya mengambil kira kerosakan yang besar [2]. Kos pengkomputeran awalan adalah tinggi tetapi memberikan diagnosis yang cepat semasa pengeluaran. Teknik moden menggunakan kepintaran tiruan termasuk dalam kategori kedua. Ianya akan menambahkan masa mendiagnosis semasa pengeluaran [3].

Sejak 1990an kajian terhadap diagnosis kerosakan litar menggunakan rangkaian

$\overline{1,2 \& 3}$ Jabatan Kejuruteraan Elektrik dan Elektronik Fakulti Kejuruteraan, Universiti Putra Malaysia, Malaysia samsul@eng.upm.edu.my 
neural tiruan telah dilaporkan [3]-[10] yang kebanyakannya menggunakan kaedah perambatan balik manakala penggunaan kaedah penggugusan samar telah dilaporkan oleh Zu dan Zhong [13].

Pelbagai litar telah digunakan sebagai litar ujian. Litar-litar penapis telah dikaji dalam [2], [3] dan [10], sebahagian dari litar pemandu dc motor dalam [4], litar perintang mudah diberikan dalam [5], penerus dalam [6] dan litar analog IC dalam [7].

Dalam kajian ini, litar pengayun dan Pulse Width Modulator iaitu sebahagian dari litar Switch Mode Power Supply telah digunakan. Litar yang sempurna disimulasi menggunakan Pspice dan nilai voltan pada nod diambil untuk mendapatkan data litar yang baik. Kemudiannya satu persatu komponen yang ada di'rosak'kan dengan menjadikannya litar pintas atau litar putus dan disimulasi serta voltan pada nod-nod direkodkan. Data-data yang diperolehi dari simulasi ini seterusnya digunakan untuk melatih RNT. Sistem rangkaian neural yang telah dilatih menggunakan algoritma perambatan balik ini digunakan untuk menguji litar. Dari ujian yang dijalankan, komponen yang rosak dapat dikenalpasti dengan tepat. Kami percaya kaedah ini boleh digunakan untuk litar yang lelurus dan tak-lelurus.

\subsection{RANGKAIAN NEURAL TIRUAN}

Kecerdikan tiruan adalah satu pembelajaran berkaitan tingkahlaku kecerdikan dan berkaitan dengan implementasi program komputer yang dapat mempamerkan tingkahlaku kecerdikan tersebut. Andaian yang paling penting dibuat oleh sistem kecerdikan yang tradisional adalah simbol fizikal bagi sistem hipotesis yang telah diutarakan oleh Newell dan Simon pada tahun 1976 yang menyatakan "A physical symbol system has the necessary sufficient means for general intelligence action" yang menerangkan kenapa bahasa kecerdikan tiruan adalah sesuai ke atas mani pulasi simbol [15].

Rangkaian neural merupakan otak, metafor di mana kecerdikan melalui elemen proses yang banyak dan berkait antara satu sama lain yang mana setiap satu menghasilkan persembahan yang ringkas.

Building block pada semua otak biologi adalah dikenali sebagai neuron. Setiap neuron bertindak sebagai unit proses numerikal yang ringkas. Setiap neuron di dalam otak mengambil masukan dari neuron yang lain dengan menggunakan fungsi pindahan dan menghantar keluaran menggunakan neuron yang seterusnya. Semua neuron ini akan menghantar keluaran ke lapisan yang lain secara berturutan atau cascade.

Lazimnya RNT terdiri dalam bentuk beratus atau beribu unit proses yang ringkas bersambung secara selari dan masukan ke hadapan di dalam beberapa lapisan. Biologi neuron yang terlalu kecil dan RNT dengan tiga lapisan digambarkan dalam Rajah 1. Lapisan masukan bertindak sebagai buffer tetapi lapisan terlindung dan keluaran mempunyai fungsi pindahan jenis sigmoid. Rangkaian neural dijelaskan oleh satu set titik anak panah yang mana tersiri dari pada konsep asas di dalam teori graf. Titik-titik ini mewakili neuron dan anak panah mewakili sambungan dengan arah aliran isyarat di antara neuron. 


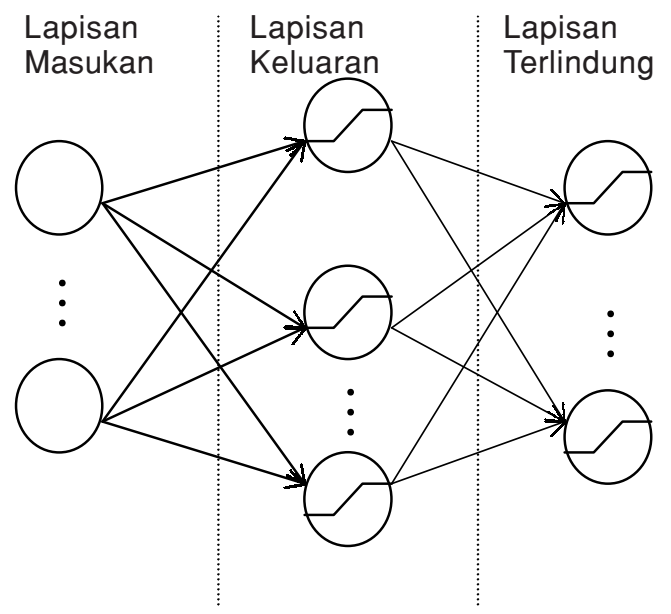

Rajah 1 Topologi rangkaian perambatan balik

Pada neuron, aktiviti keluaran pada aras penggiatan yang rendah, penggiatan yang sederhana melampaui pada sesuatu tahap keluaran dan keluaran yang tepu untuk masukan kepada tahap yang lebih besar. Di dalam rangkaian kecerdikan tiruan, fungsi sigmoid selalunya digunakan sebagai fungsi pindahan. Rangkaian neural dapat mengenalpasti, mengklasifikasi, mengubah dan belajar corak. Corak ini adalah penghuraian tentang objek atau konsep. Pengenalpastian corak ini merujuk kepada kategori data masukan ke dalam kelas yang tertentu dengan mengenalpasti data-data tersebut.

Selalunya rangkaian neural disimulasi menggunakan program komputer. Walaupun bahasa perisian yang biasa digunakan untuk encode simulasi RNT, tetapi terdapat beberapa kekunci yang berbeza di antara menulis program yang biasa dan menggunakan RNT. Semua perbezaan ini ditumpukan kepada manusia seperti asli oleh RNT adalah:

(1) RNT dilatih bukan di program.

(2) Rangkaian ini belajar perhubungan di antara perubahan dengan sendirinya.

(3) Rangkaian ini dipanggil dari memorinya.

(4) Latihan yang berlebihan untuk rangkaian itu dapat memberikan keputusan di dalam memori bagi corak latihan.

\subsection{PERIHAL PERISIAN}

\subsection{PSpice}

PSpice merupakan satu perisian yang digunakan untuk melukis litar elektrik secara skematik. Nod-nod voltan, arus atau frekuensi masukan dan keluaran ditandakan pada mana-mana tempat dalam litar. Simulasi boleh dilaksanakan apabila litar tersebut telah dilengkapkan dan seterusnya voltan, arus atau frekuansi pada nod-nod masukan 
dan keluaran direkodkan.

Untuk melukis litar komponen-komponen boleh diperolehi dari library. Keputusan simulasi boleh dipaparkan dalam bentuk graf atau jadual untuk analisis selanjutnya.

\subsection{Extend}

Perisian yang digunakan untuk menjalankan RNT ini adalah perisian Extend. Di mana perisian ini merupakan perisian yang memaparkan bantuan membuat satu keputusan untuk model yang telah ditentukan. Penggunaan perisian ini adalah sebagai satu percubaan untuk membuat model RNT. Ini merupakan satu alternatif untuk menjalankan RNT selain daripada membuat model RNT menggunakan program C. Perisian ini merupakan satu penggunaan berpersekitarankan windows.

Di dalam perisian ini terdapat apa yang dikenali sebagai NeuroLab iaitu rangkaian neuron bagi simulasi blok untuk program Extend ini. Ini merupakan alat yang efektif untuk pemahaman, merekabentuk dan simulasi sistem rangkaian neural. Blok yang terdapat di dalam library ini dapat digunakan dengan blok Extend yang lain untuk merekabentuk aplikasi yang kompleks untuk rangkaian neural ini. NeuroLab ini mengandungi lebih kurang 70 blok untuk implementasikan rangkaian neural tiruan ini. Library ini bertujuan membantu pengguna memahami asas rangkaian neural dan membekalkan alat untuk simulasi aplikasi rangkaian neural.

Fungsi blok dalam NeuroLab diatur dan disusun untuk memenuhi permintaan semua peringkat pengguna. Sebagai contoh blok pendidikan akan membantu pengguna yang baru menggunakan perisian ini untuk memahami sistem neural di mana setiap blok direka untuk memperlihatkan pengiraan matematik di dalam rangkaian neural dengan terperinci.

Untuk membuat model pula pengguna dapat membina rangkaian neural dari neuron individu, rangkaian satu lapisan atau pelbagai lapisan berdasarkan blok yang telah digunakan.

\subsection{KAEDAH}

\subsection{Pelaksanaan PSpice}

Litar Switch Mode Power Supply yang lengkap dengan komponen elektrik seperti transistor, kapasitor, perintang dan lain-lain didapati. Litar tadi disimulasikan dengan menggunakan perisian PSpice untuk mendapatkan data-data bagi nilai voltan, arus, frekuensi yang merupakan nilai-nilai yang penting bagi membolehkan litar tersebut berfungsi. Lebih banyak data adalah lebih baik untuk membantu melatih RNT dan bagi mendapatkan jawapan yang sebaik mungkin. Sesudah semua data yang dikehendaki untuk satu litar tanpa kerosakan diperolehi, data bagi komponen yang dirosakkan pula diambil. Data ini diambil pada titik yang sama dengan data yang diambil bagi litar tanpa kerosakan. Untuk tujuan ini, komponen pada litar tersebut akan dirosakkan dan kemudian data bagi setiap keluaran akan diambil. Komponen 
ini akan dirosakkan satu persatu dan data juga diambil satu persatu. Untuk projek ini data yang diambil adalah sebanyak enam belas kemungkinan berlakunya kerosakan. Untuk tujuan kajian ini, litar yang dikaji merupakan sebahagian dari Switch Mode Power Supply iaitu blok bagi litar pengayun dan pulse width modulation.

\subsection{Pelaksanaan RNT}

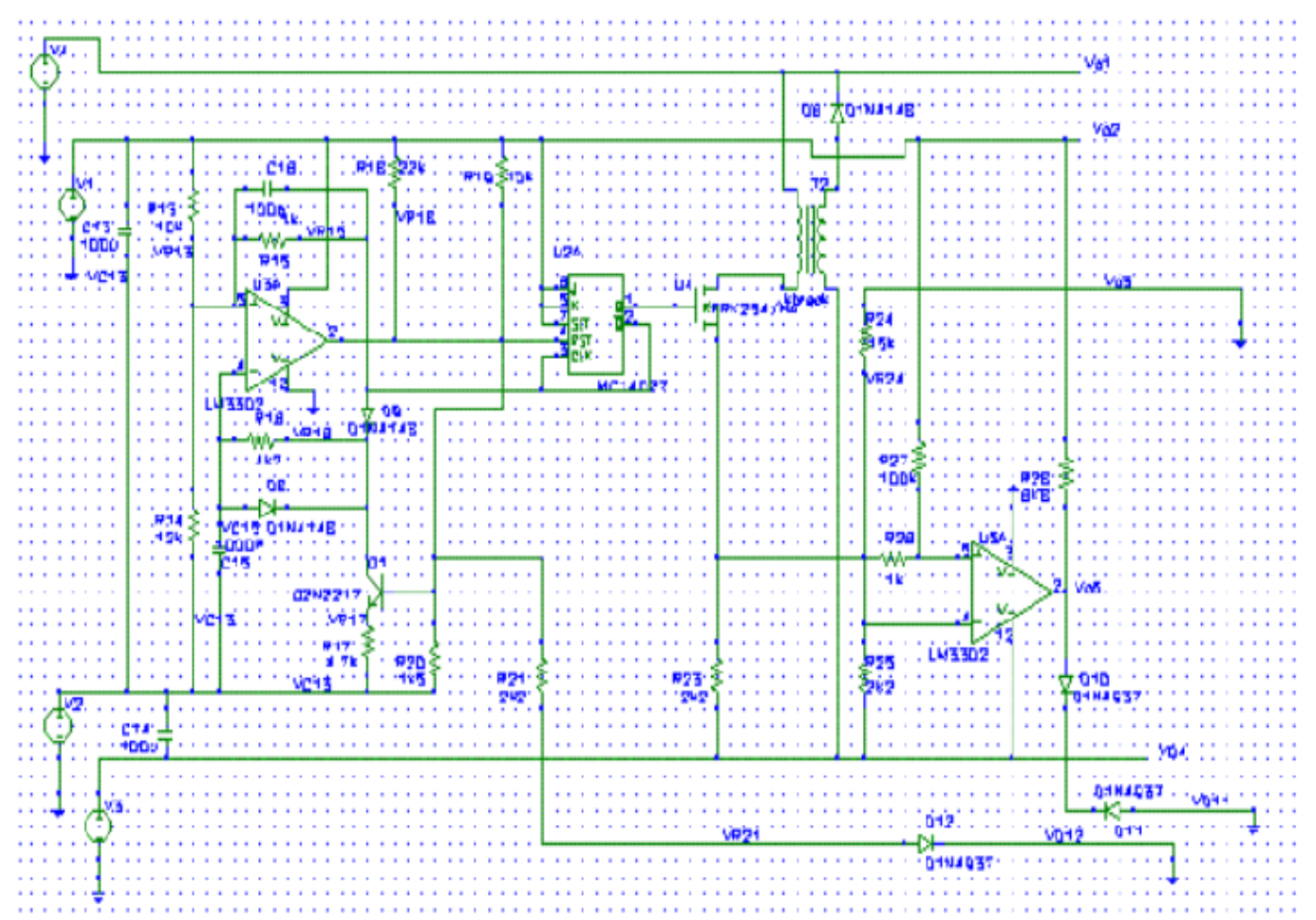

Rajah 2 Litar Pengayun dan Pulse Width Modulator

Data-data yang diperolehi dari simulasi PSpice digunakan bagi melatih RNT untuk mengesan kerosakan. Untuk satu RNT yang ringkas terdapat tiga iaitu lapisan masukan, lapisan terlindung dan lapisan keluaran. Kesemua data akan dimasukkan pada lapisan masukan. Dari lapisan masukan ini data akan diproses dengan menentukan nilai pemberat. Sesudah nilai pemberat diketahui lapisan masukan akan menghantar data tadi kepada lapisan terlindung. Pada bahagian ini pemberat akan menetapkan nilai pemberatnya dan seterusnya akan mengesan dan menentukan kesemua data yang digunakan mempunyai satu nilai pemberat yang tetap. Sebelum proses ini dilakukan, nilai keluaran yang dikehendaki akan ditetapkan. Selepas melalui lapisan terlindung keluaran dari lapisan ini hendaklah sama dengan nilai keluaran yang ditetapkan. Selagi nilai keluaran tidak menepati atau tidak sama dengan nilai keluaran yang telah 
ditetapkan, maka pemberat akan berubah dengan sendirinya sehinggalah mencapai keluaran yang telah ditetapkan tadi. Seterusnya data akan dikeluarkan melalui lapisan keluaran. Data-data ini akan digunakan sebagai perbandingan untuk mengesan kerosakan di dalam litar tersebut.

Rajah 3 menunjukkan carta alir untuk menunjukkan proses pengambilan data dari PSpice dan proses pembelajaran dalam RNT. Sistem RNT ini mempunyai sepuluh masukan, dua lapisan terlindung dan empat keluaran.

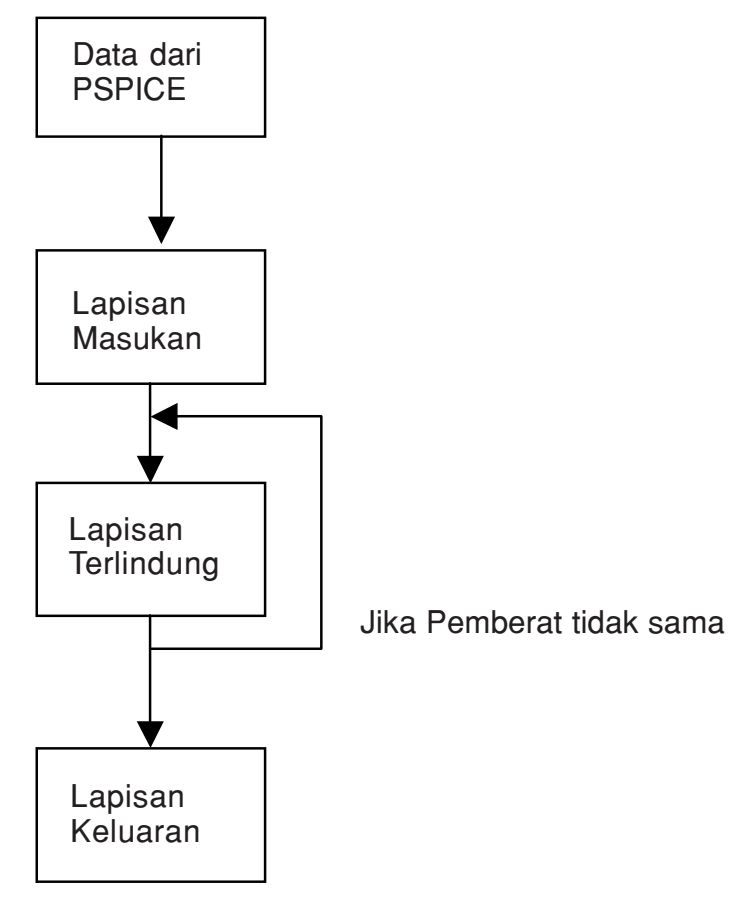

Rajah 3 Carta alir bagi proses pembelajaran bagi RNT

Rajah 4 merupakan gambarajah blok yang telah dijanakan bagi menjalankan sistem RNT ini. Ia terdiri dari blok bagi data masukan, dual shift register, masukan $M N N$, lapisan terlindung, lapisan keluaran, fail masukan $M N N$ pemberat dan bias, kawalan $M N N B P$, fail keluaran $M N N$ dan penunjuk nilai matriks.

Data masukan merupakan tempat di mana data dimasukkan bagi menguji sistem ini. Untuk tujuan itu 'Input Sequence Block' telah digunakan. Dengan menggunakan blok ini masukan kepada rangkaian model dapat dimasukkan dari masa ke semasa mengikut data yang hendak diuji.

Blok 'dual shift register' digunakan bagi tujuan memani pulasi isyarat yang hendak dihantar dan membina siri masa bagi data untuk tujuan mengenalpasti data yang dimasukkan iaitu data yang hendak diuji. 


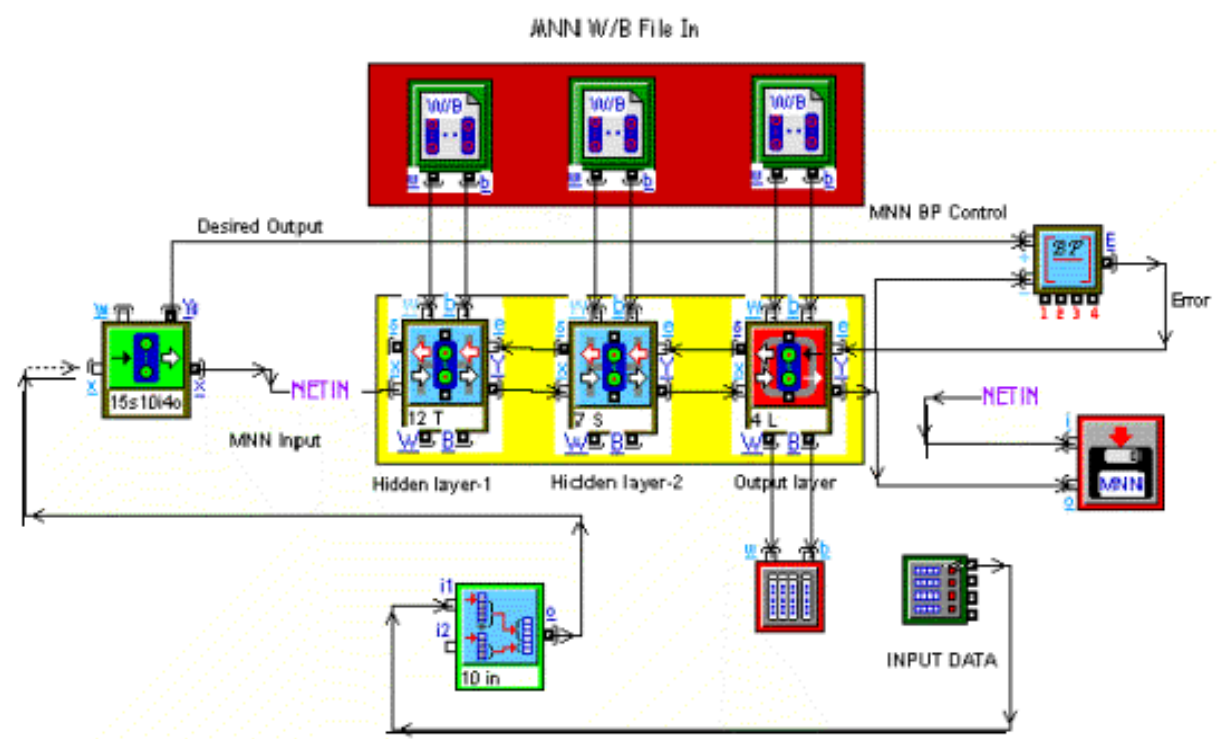

Rajah 4 Sistem RNT di dalam perisian perisian Extend

Blok masukan $M N N$ merupakan blok yang mewakili lapisan masukan. Pada blok ini ditetapkan sebanyak mana kemungkinan rosak yang akan berlaku dan disertakan dengan keluaran yang dikehendaki bagi setiap masukan yang akan diuji.

Blok lapisan terlindung merupakan blok yang mewakili lapisan terlindung. Untuk lapisan terlindung ini digunakan dua lapisan. Kedua-dua lapisan ini akan menjadi neuron dalaman yang akan digunakan bagi tugas sebagai otak dalaman.

Blok lapisan keluaran merupakan blok yang mewakili keluaran dari lapisan terlindung. Blok ini akan menyimpan data yang diperolehi dari lapisan terlindung.

Blok fail masukan $M N N W / B$ memaparkan perubahan berat bagi sistem ini hingga masukan akan memberikan keluaran yang ditetapkan. Setelah keluaran yang dikehendaki berpadanan dengan masukan, maka nilai bagi pemberat akan tetap dan seterusnya tidak akan berubah sehinggalah terdapat nilai baru yang hendak dijanakan.

Blok kawalan $M N N B P$ merupakan blok di mana ke semua nilai keluaran dari lapisan keluaran dan masukan akan dibandingkan di sini. Selagi masukan tidak berpadanan dengan keluaran maka ia akan menghantar isyarat yang menunjukkan simulasi belum lengkap ke lapisan masukan dan keluaran seterusnya melatih semula RNT sehingga masukan dan keluaran berpadanan dengan apa yang dikehendaki.

Blok fail keluaran $M N N$ merupakan blok dimana semua keluaran dibaca dan disimpan sebagai teks bagi dibaca oleh pengguna untuk mengesan kerosakan. Fail ini akan memaparkan masukan dan keluaran hasil dari sistem RNT yang telah dijanakan ini.

Blok bagi matrix value display pula digunakan bagi memaparkan nilai pemberat yang terakhir. Data-data bagi kesemua nilai pemberat ini dipaparkan dalam bentuk susunan matriks. 


\subsection{KEPUTUSAN}

Sistem asas bagi RNT merupakan lapisan masukan, lapisan terlindung dan lapisan keluaran. Untuk kajian ini dua lapisan terlindung digunakan. Masukan dan keluaran yang berpadanan dengannya dimasukkan dan dilatih di dalam sistem asas ini. Apabila ia disimulasikan data masukan dan data keluaran yang ditetapkan akan dibaca dan perubahan berat pada setiap lapisan akan berlaku. Perubahan berat ini akan berhenti berubah sehinggalah sistem dapat membaca masukan dan keluaran yang ditetapkan itu. Sementara itu blok kawalan $B P$ akan menentukan samada keluaran yang diperolehi sama atau tidak. Jika sama atau apa yang dikehendaki telah dicapai maka kawalan $B P$ akan memberikan isyarat untuk memberhentikan simulasi dan jika tidak ia akan meneruskan simulasi sehingga apa yang dikehendaki dicapai.

Sesudah sistem asas dapat menentukan masukan dan keluaran maka data yang hendak diuji dimasukkan menerusi blok input sequence. Data dari sini dihantar ke lapisan masukan melalui blok dual shift register di mana menerusi blok ini data akan dimanipulasi dan ditetapkan siri masa bagi data tersebut untuk proses mengenalpasti data tersebut.

Sesudah data masukan itu dikenalpasti maka ia akan dihantar ke sistem asas RNT yang telah dijana sebelum ini. Dalam sistem ini data-data tersebut akan diuji sebelum pengesanan. Sistem RNT akan mengesan data-data ini dan seterusnya membaca dan membandingkan data masukan ini dengan data-data yang telah dilatih dalam sistem ini. Sesudah dibandingkan dan keluaran dapat ditetapkan maka sistem akan menghantar keputusan ke fail keluaran yang ada iaitu fail keluaran $M N N$ di mana fail ini akan memberikan keputusan akhir kepada pengguna. Dari fail ini pengguna dikehendaki membandingkan keputusan dengan data di dalam manual yang disediakan untuk mengetahui komponen yang rosak.

\subsection{Data Masukan}

Jadual 1 menunjukkan senarai data yang diperolehi dari simulasi litar Switch Mode Power Supply untuk blok litar pengayun dan pulse width modulation yang diambil dari sepuluh titik yang ditetapkan. Ini adalah bertujuan untuk mendapatkan data-data masukan bagi melatih RNT dan menguji sistem RNT yang telah dijanakan.

\subsection{Data Keluaran Dan Diagnosis Komponen Rosak}

Jadual 2 menunjukkan senarai keluaran yang sepatutnya dan berpadanan dengan kerosakan komponen. Senarai ini juga merupakan manual untuk digunakan bagi mengetahui komponen yang rosak berdasarkan keluaran yang diperolehi. Dengan berpandukan kepada manual atau senarai ini pengguna yang menguji kerosakan bagi komponen dalam litar bagi blok pengayun dan pulse width modulation ini dapat mengetahui komponen yang rosak dengan mudah iaitu dengan membandingkan data keluaran yang diperolehi dari simulasi RNT dengan senarai manual ini. 
Jadual 1 Data-data masukan bagi melatih RNT

\begin{tabular}{|l|c|c|c|c|c|c|c|c|c|c|}
\hline \multicolumn{1}{r|}{ TITIK } & Vo4 & Vo1 & Vo15 & Vo5 & VC13 & VC15 & VR13 & VR15 & VR16 & VR17 \\
MASUKAN & & & & & & & & & & \\
\hline DATA 1 & 0 & 20 & 15 & 14.9 & 5 & 10.5 & 10.45 & 10.45 & 10.52 & 5 \\
\hline DATA 2 & 0 & 20 & 15 & 14.9 & 5 & 14.2 & 10.45 & 10.45 & 14.2 & 14.2 \\
\hline DATA 3 & 0 & 20 & 15 & 14.9 & 5 & 14.2 & 10.45 & 10.45 & 14 & 14.2 \\
\hline DATA 4 & 0 & 20 & 15 & 14.9 & 5 & 10.5 & 10.45 & 10.45 & 5 & 0.1 \\
\hline DATA 5 & 0 & 20 & 15 & 14.9 & 0 & 5 & 7.9 & 7.4 & 6.9 & 5 \\
\hline DATA 6 & 0 & 20 & 15 & 14.9 & 0 & 10.5 & 10.45 & 10.45 & 10.5 & 5 \\
\hline DATA 7 & 0 & 20 & 15 & 14.9 & 5 & 10.5 & 10.45 & 10.45 & 10.5 & 5 \\
\hline DATA 8 & 0 & 20 & 15 & 14.9 & 5 & 10.5 & 10.45 & 10.45 & 5 & 5 \\
\hline DATA 9 & 0 & 20 & 15 & 14.9 & 5 & 10.5 & 10.4 & 10.4 & 10.5 & 5 \\
\hline DATA 10 & 0 & 20 & 5 & 4.9 & 5.1 & 5 & 5 & 5 & 5 & 0.1 \\
\hline DATA 11 & 0 & 20 & 15 & 14.9 & 5 & 15.1 & 15 & 15.1 & 5 & 0.1 \\
\hline DATA 12 & 0 & 20 & 15 & 14.9 & 5 & 15.1 & 15 & 15 & 5 & 0.1 \\
\hline DATA 13 & 0 & 20 & 15 & 14.9 & 5.1 & 5 & 5.1 & 5 & 5.1 & 5 \\
\hline DATA 14 & 0 & 20 & 15 & 14.9 & 5 & 15.1 & 15.2 & 15.1 & 5 & 0.1 \\
\hline DATA 15 & 0 & 20 & 15 & 14.9 & 5 & 10.5 & 10.45 & 10.45 & 10.5 & 0 \\
\hline
\end{tabular}

Jadual 2 Data keluaran dan komponen rosak

\begin{tabular}{|c|c|c|}
\hline $\begin{array}{c}\text { BILANGAN } \\
\text { UJIAN }\end{array}$ & $\begin{array}{c}\text { KOMPONEN } \\
\text { ROSAK }\end{array}$ & KELUARAN \\
\hline 0 & TIADA & 0000 \\
\hline 1 & $\mathrm{R} 13$ & 0001 \\
\hline 2 & R14 & 0010 \\
\hline 3 & R15 & $\begin{array}{llllll}0 & 0 & 1 & 1\end{array}$ \\
\hline 4 & C16 & 0100 \\
\hline 5 & $\mathrm{R} 18$ & 0101 \\
\hline 6 & R19 & 01110 \\
\hline 7 & R16 & 01111 \\
\hline 8 & $\mathrm{C} 15$ & 1000 \\
\hline 9 & R17 & 1001 \\
\hline 10 & R21 & 1010 \\
\hline 11 & R23 & 1011 \\
\hline 12 & $\mathrm{R} 13, \mathrm{R} 14$ & 1100 \\
\hline 13 & R18, R19 & 1101 \\
\hline 14 & $\mathrm{C} 16, \mathrm{C} 15$ & 1110 \\
\hline 15 & R20, R21 & 1111 \\
\hline
\end{tabular}


(a) $\mathrm{KES} 1$

\begin{tabular}{|c|c|}
\hline TITIK & $\begin{array}{c}\text { MASUKAN } \\
\text { DARI } \\
\text { PSPICE }\end{array}$ \\
\hline Vo4 & 0 \\
\hline Vo1 & 20 \\
\hline Vo15 & 15 \\
\hline Vo5 & 14.9 \\
\hline VC13 & 5 \\
\hline VC15 & 10.5 \\
\hline VR13 & 10.45 \\
\hline VR15 & 10.45 \\
\hline VR16 & 10.52 \\
\hline VR17 & 5 \\
\hline
\end{tabular}

(b) KES 2

\begin{tabular}{|c|c|}
\hline TITIK & $\begin{array}{c}\text { MASUKAN } \\
\text { DARI } \\
\text { PSPICE }\end{array}$ \\
\hline Vo4 & 0 \\
\hline Vo1 & 20 \\
\hline Vo15 & 15 \\
\hline Vo5 & 14.9 \\
\hline VC13 & 5 \\
\hline VC15 & 14.2 \\
\hline VR13 & 10.45 \\
\hline VR15 & 10.45 \\
\hline VR16 & 14 \\
\hline VR17 & 14.2 \\
\hline
\end{tabular}

(c) KES 3

\begin{tabular}{|c|c|}
\hline TITIK & $\begin{array}{c}\text { MASUKAN } \\
\text { DARI } \\
\text { PSPICE }\end{array}$ \\
\hline Vo4 & 0 \\
\hline Vo1 & 20 \\
\hline Vo15 & 15 \\
\hline Vo5 & 14.9 \\
\hline VC13 & 5 \\
\hline VC15 & 10.5 \\
\hline VR13 & 10.45 \\
\hline VR15 & 10.45 \\
\hline VR16 & 5 \\
\hline VR17 & 0.1 \\
\hline
\end{tabular}

Jadual 3 Contoh-contoh diagnosis

\begin{tabular}{|c|c|}
\hline $\begin{array}{c}\text { KELUARAN } \\
\text { SISTEM } \\
\text { RNT }\end{array}$ & $\begin{array}{c}\text { KELUARAN } \\
\text { SISTEM } \\
\text { LOGIK }\end{array}$ \\
\hline 0.88248588 & 1 \\
0.11808413 & 0 \\
0.27290928 & 0 \\
0.098188186 & 0 \\
\hline
\end{tabular}

\begin{tabular}{|c|c|}
\hline $\begin{array}{c}\text { KELUARAN } \\
\text { SISTEM } \\
\text { RNT }\end{array}$ & $\begin{array}{c}\text { KELUARAN } \\
\text { SISTEM } \\
\text { LOGIK }\end{array}$ \\
\hline 0.10063008 & 0 \\
0.34758917 & 0 \\
0.65592067 & 1 \\
0.96414427 & 1 \\
\hline
\end{tabular}

\begin{tabular}{|c|c|}
\hline $\begin{array}{c}\text { KELUARAN } \\
\text { SISTEM } \\
\text { RNT }\end{array}$ & $\begin{array}{c}\text { KELUARAN } \\
\text { SISTEM } \\
\text { LOGIK }\end{array}$ \\
\hline 0.85140072 & 1 \\
0.0072220021 & 0 \\
0.90256172 & 1 \\
0.89089304 & 1 \\
\hline
\end{tabular}


Jadual 3 menunjukkan contoh keluaran pada sistem RNT yang telah dibina ini dan juga bagaimana cara pengguna membaca data yang diperolehi. Keluaran ditukar kepada nilai logik 0 sekiranya nilainya kurang daripada 0.5 dan logik 1 sekiranya nilai lebih dari 0.5. Data yang diperolehi dibandingkan dengan Jadual 2 untuk mengetahui di mana kerosakan itu berlaku.

Berdasarkan kepada Jadual 3 (a), keluaran adalah 1000 dan berdasarkan Jadual 2, ia menunjukkan kerosakan pada komponen C15. Bagi kes 2 dalam Jadual 3(b), kerosakan berlaku pada pada komponen R15 manakala kes 3 menunjukkan kerosakan pada komponen R23.

\subsection{KESIMPULAN}

Litar pengayun dan pulse width modulation yang merupakan sebahagian dari litar SMPS telah disimulasikan. Voltan-voltan pada sepuluh nod telah direkodkan. Data ini telah digunakan untuk melatih sistem RNT berasaskan perambatan balik yang boleh digunakan untuk mendiagnosis kerosakan litar. Ujian yang dijalankan menunjukkan sistem RNT ini dapat mengenalpasti komponen yang rosak dengan pantas melainkan kerosakan yang berlaku memberikan keluaran yang serupa pada sepuluh nod tersebut. Ketepatan keluaran sistem RNT yang dibangunkan ini boleh ditingkatkan dengan menambah latihan kepada setiap set data masukan. Hasil kajian ini memberikan keyakinan bahawa sistem ini boleh dilaksanakan ke atas litar sebenar.

\section{RUJUKAN}

[1] Bandler,J. W., and A. E. Salama. 1985. "Fault diagnosis of analog Circuits". Proc. IEEE. 73(8): 1279-1325.

[2] Prasad, V. C., and N. S. Chandra Babu. 2000. "Selection of Test Nodes for Analog Fault Diagnosis in Dictionary Approach". IEEE Trans. On Instrumentation and Measurement. 49(6).

[3] Spina, R., and S. Upadhyaya. 1997. "Linear Circuit Fault Diagnosis Using Neuromorphic Analyzers". IEEE Trans. On Circuits and Systems - II: Analog and Digital Signal Processing. 44(3).

[4] Fanni, A., A. Giua, M. Marchesi, and A. Montisci. 1999. "A Neural Network Diagnosis Approach for Analog Circuits". J. of Applied Intelligence. pp. 1-20.

[5] Mohammadi, K. A. R. Mohseni Monfared, and A. Molaei Nejad. 2002. "Fault Diagnosis of Analog Circuits with Tolerances by using RBF and BP Neural Networks”. Proc. IEEE Student Conference on Research and Development, Shah Alam, Malaysia.

[6] Hao Ma, Dehong Xu and Yim-Shu Lee. 1999. "Fault Diagnosis of Power Circuits based on neural Network and Waveform Analysis”. Proc. IEEE Int. Conference on Power and Drive Systems. Hong Kong.

[7] Yang, Z. R., M. Zwolinski, C. D. Chalk, and A. C. Williams. 2000. "Applying a Robust Heteroscedatic Probabilistic Neural Network to Analog Fault Detection and Classification”. IEEE Trans. On Computer-Aided Design of Integrated Circuits and Systems. 19(1).

[8] Kirkland, L. V., J. S. Dean, and M. Harm. 1995. "Monitoring Power Supply Current and Using Neural Network Routine to Doagnose Circuit Faults". IEEE Aerospace and Electronic Systems Magazines.

[9] Fedi, G., S. Manetti, and M. C. Piccirilli. 1999. "Comments on Linear Circuit Fautl Diagnosis Using Neromorphic Analyzers”. IEEE Trans. On Circuits and Systems - II: Analog and Digital Signal Processing. $46(4)$.

[10] Aminian M., and F. Aminian. 2000. "Neural-Network Based Analog-Circuit Fault Diagnosis Using Wavelet Transform as Preprocessor”. IEEE Trans. On Circuits and Systems - II: Analog and Digital Signal Processing. $47(2)$. 
[11] Worsman, M., and M. W. T. Wong. 1998. "Nonlinear Circuit Fault Diagnosis With Large Change Sensitivity". IEEE Int. Conf. on Electronics, Circuits and Systems. 2. pp. 225-2228.

[12] Somayajula, S., S. E. Sanchez-Sinenco, and Jose Pineda de Gyvez. 1993. "Analog Fault Diagnosis: A Fault Clustering Approach". Proc. of European Test Conference. p108-115.

[13] Zi-Chen Hu, and Ping Zhong. 1991. "A Direct Cluster Method to Analogue Circuits Fault Diagnosis”. China Int. Conf. on Circuits and Systems, Shenzen, China. pp520-522.

[14] Luchetta, A., S. Manetti, and M. C. Piccirilli. 2002. "Critical Comparison Among Some Analog Fault Diagnosis Procedures based on Symbolic Techniques”. Proc. Design, Automation and Test in Europe Conference and Exhibition.

[15] Haykin, S. 1994. Neural Networks: A Comprehensive Foundation. Macmillan College Publishing Company. 